\title{
MIGRATION OF BIOGENIC ELEMENTS COMPOUNDS IN THE APPLICATION OF COMPLEX INOCULANT FOR SOYBEAN
}

\author{
S. F. Kozar, T. A. Yevtushenko, L. V. Potapenko, Ye. P. Chmel \\ Institute of Agriculture Microbiology and Agroindustrial Manufacture, NAAS, \\ 97, Shevchenka Str., City of Chernihiv, 14027 \\ E-mail: ismav@online.ua
}

In lysimetric experiment with soybean, the effect of complex inoculants based on Bradyrhizobium japonicum and Azospirillum brasilense on the vertical migration of biogenic elements have been studied. When growing without application of mineral fertilizers, bacterization helped to reduce losses of nitrogen, phosphorus, potassium, calcium, magnesium compounds, as well as moisture and water-soluble humus. Also reduction in loss of biogenic elements compounds under the action of inoculants on the background of $N_{30}$ was found, but bacterization not affect the loss of moisture and humus. It was shown that complex inoculants affect biometric parameters of soybean plants and enhances the productivity of this culture.

Kew words: inoculant, soybean, lysimetric experiments, biogenic elements.

Currently, topical issue is the use of nitrogen-fixation bacteria to increase crop yields and improve the quality of received products through seed pre-processing with microbial drugs [1-3]. For soybean, essential element of cultivation technology is the use of highly efficient inoculants based on bacteria Bradyrhizobium japonicum. At the same time, the basic requirements for modern agrarian technologies include provision the level of yield of crops according to the variety potentials. The most important techniques for soybean cultivation should include a system of its fertilization that should be obligatory combined, since this culture can adopt a certain part nitrogen compounds in symbiosis with microorganisms. However, up to the present time the effect of combination of agronomic measures, especially, application of low norms of nitrogen mineral fertilizers and use of microbial inoculants on the migration of compounds of biogenic elements under cultivation of legumes that is important for assessment of technologies of their cultivation in terms of resource conservation have not been fully established.

The aim of our work was to investigate the effect of new complex inoculants based on diazotrophs Bradyrhizobium japonicum and Azospirillum brasilense under the conditions of lysimetric experiments on the intensity of migration of compounds of biogenic elements outside root-containing layer of soil under cultivation of soybean without fertilization and at the background of $\mathrm{N}_{30}$.

Materials and methods. Impact of pre-processing bacterization of soybean with inoculants based on rhizobia and azospirilla with and without sodium alginate was studied under conditions of lysimetric apparatus of the Institute of Agricultural Microbiology and Agroindustrial Manufacture of the NAAS that has 48 lysimetric sections laced in two parallel rows of 24 lysimetric apparatuses in each. Receiving vessels for filtrate collection are set under them. According to the construction lysimetric apparatuses are concrete, bulk type. Lysimetric cells are filled with soil sequentially, ranging from parent material considering genetic horizon power. Sown area of lysimetric cell is $3.8 \mathrm{~m}^{2}$. Layer of soil is $155 \mathrm{~cm}$, its weight is 10.5 t. Soil in lysimetric apparatuses is sod podzolic loamy with such characteristic of top soil $(0-23 \mathrm{~cm})$ : content of humus by 
Tiuryn $-1.1 \%$, $\mathrm{pH}$ of salt extraction -5.5 ; hydrolytic acidity (by Kappen) - $2.5 \mathrm{mEq}$ per $100 \mathrm{~g} ; \mathrm{P}_{2} \mathrm{O}_{5}$ content (by Kirsanov) $170.0 \mathrm{mg} ; \mathrm{K}_{2} \mathrm{O}$ (by Maslova) - $62.0 \mathrm{mg} / \mathrm{kg}$ of soil.

Content of nitrates was measured by disulfonic, ammonium nitrogen - with Nessler reagent, water-soluble $\mathrm{P}_{2} \mathrm{O}_{5}-$ by Kirsanov, $\mathrm{K}_{2} \mathrm{O}$ - by flame-photometric method, $\mathrm{CaO}$ and $\mathrm{MgO}$ - by complexometry, water soluble humus - by Tiuryn [4].

Strains of bacteria Bradyrhizobium japonicum M-8 [5] and Azospirillum brasilense 410 [6], cultured with and without the addition sodium alginate to the digest medium for its sensitisation and increase of diazotrophs viability were used [7]. Microorganisms were obtained from the collection of beneficial soil microorganisms of the Institute of Agricultural Microbiology and Agroindustrial Manufacture of the NAAS. We express our sincere gratitude to the authors for kindly procured strains.

Studies with soybean of variety Lehenda was performed in 2016; replication of the experiment is four-time. The scheme of the experiment included two blocks without fertilization and with application of mineral nitrogen $\left(\mathrm{N}_{30}\right)$, each of which include the following options:

1) without inoculants (control);

2) inoculant 1 (Bradyrhizobium japonicum M-8 and Azospirillum brasilense 410);

3) inoculant 2 (based on B. japonicum M-8 and A. brasilense 410, with addition of sodium alginate).

Collect and registration of harvest was carried out by direct method. Statistical processing of the obtained results was carried out by Dospiekhov [8].

Investigated microorganisms were cultivated under conditions of periodic cultivation in microbiological shaker at $220 \mathrm{rpm}$ at temperature of $28^{\circ} \mathrm{C}$. Seeding culture of $A$. brasilense was cultivated in a liquid digest medium with the following composition $\left(\mathrm{g} / \mathrm{dm}^{3}\right)$ : maize extract - 30.0; molasses - 30.0; $\left(\mathrm{NH}_{4}\right)_{2} \mathrm{SO}_{4}-0.10 ; \mathrm{KH}_{2} \mathrm{PO}_{4}$ - $\quad 0.25 ; \quad \mathrm{K}_{2} \mathrm{HPO}_{4} \bullet 3 \mathrm{H}_{2} \mathrm{O} \quad-\quad 0.25$; $\mathrm{MgSO}_{4} \bullet 7 \mathrm{H}_{2} \mathrm{O}-0.20 ; \mathrm{CaCO}_{3}-0.30$.
Sowing culture of $B$. japonicum was grown in a liquid digest medium of the following composition $\left(\mathrm{g} / \mathrm{dm}^{3}\right)$ : pea seeds decoction 100; glucose - 10; sucrose - 5; $\left(\mathrm{NH}_{4}\right)_{2} \mathrm{SO}_{4}-$ 1.0; $\mathrm{KH}_{2} \mathrm{PO}_{4}-0.5 ; \mathrm{K}_{2} \mathrm{HPO}_{4} \bullet 3 \mathrm{H} 2 \mathrm{O}-0.5$; $\mathrm{MgSO}_{4} \bullet 7 \mathrm{H}_{2} \mathrm{O}-0.2 ; \mathrm{CaCO}_{3}-0.3$. Cocultivation of bacteria $A$. brasilense and $B$. japonicum was performed by using a digest medium for mixed cultivation of rhizobia and azospirilla [9].

Measurement of nitrogen fixation activity of microorganisms in symbiosis with soybean plants was performed by acetylene method on the gas chromatograph Chrom-4 with a flame-ionization detector on a column with $\beta$ - $\beta$-oxydipropionitrile [10].

Thus, the use of complex inoculants based on Bradyrhizobium japonicum and Azospirillum brasilense in technology of soybean cultivation under different backgrounds of fertilization provides reduction of the loss of compounds of biogenic elements. At the same time, inoculation influences biometric indicators on soybean plants and enhances increase of productivity of this crop by $14-28 \%$. 